\title{
SUPERVISI AKADEMIK KEPALA SEKOLAH
}

\author{
AULIA RISKI \\ Universitas Negeri Padang \\ auliariski45@gmail.com
}

\begin{abstract}
Untuk melaksanakan supervisi akademik secara efektif diperlukan keterampilan konseptual, interpersonal dan teknik (Glickman, C.D., Gordon, S.P., and RossGordon, 2007) .Oleh sebab itu, setiap Kepala Satuan Pendidikan harus memiliki dan menguasai konsep supervisi akademik yang meliputi: pengertian, tujuan dan fungsi, prinsip-prinsip, dan dimensi-dimensi substansi supervisi akademik. Kompetensi supervisi akademik intinya adalah membina dosen atau instruktur dalam meningkatkan mutu proses pembelajaran. Oleh sebab itu sasaran supervisi akademik adalah dosen atau instruktur dalam proses pembelajaran, yang terdiri dar materi pokok dalam proses pembelajaran, penyusunan silabus dan RPP, pemilihan strategi/metode/teknik pembelajaran, penggunaan media dan teknologi informasi dalam pembelajaran, menilai proses dan hasil pembelajaran serta penelitian tindakan kelas. Oleh karena itu, tujuan umum pengembangan BBM ini adalah untuk meningkatkan kompetensi supervisi akademik yang meliputi (1) perencanaan program supervisi akademik, (2) pelaksanaan program supervisi akademik dan (3) menindaklanjuti program supervisi akademik.
\end{abstract}

Keywords : supervisi akademik; kepala sekola;, teknik ; pembelajaran.

\section{PENDAHULUAN}

Dalam

menyelenggarakan pendidikan,setiap Negara pasti mendambakan peningkatan mutu dan kualitas pendidikan. Meningkatkan mutu pendidikan bukan persoalan yang gampang, begitulah kata para pakar pendidikan. Dibutuhkan rumusan konsep yang jelas, prioritas-prioritas program yang sesuai dengan kebutuhan masyarakat baik secara nasional maupun global. Sehingga menghasilkan produk yang benar-benar berkualitas yang keluar dari pemikiran yang cerdas, inovatif dan up to date. Sesuatu yang bebar-benar berbeda dan lebih baik dari yang sebelumnya sehingga lebih diminati dan mampu bersaing di dunia internasional.

Dalam upaya berinofasi dalam programprogram pendidikan, tentunya tidak dapat dilepaskan dari managemen pendidikan. Yaitu upaya maksimal dalam suatu aktifitas dan proses mendayagunakan sumber daya organisasi untuk mencapai tujuan yang ditetapkan. Manajemen dalam konteks ini sangat menentukan dan memiliki posisi yang sangat strategis, mengingat visi dan misi adalah aspek yang wajib diprioritaskan. Dalam tataran manajemen proses perencanaan (planning), mengorganisasian (organizing), penggerakan (actuating), pengendalian (controlling). Pada proses controlling inilah peran supervisor atau pengawas pendidikan sangat dibutuhkan. Ada juga yang menambahkan tahap evaluating dalam proses manajemen lembaga pendidikan. Langkah kongkrit tersebut adalah program MONEV (monitoring dan evaluasi).

Monitoring dan Evaluasi (MONEV) ada dua, pertama evaluasi atau audit internal lembaga atau sering disebut dengan audit internal. Audit internal ini bisa jadi dilaksanakan oleh kepala atau pimpinan lembaga pendidikan itu sendiri atau tim 
monev internal yang ditunjuk dan diberi SK oleh kepala atau pimpinan sekolah. Tentunya anggota tim evaluasi atau audit internal lembaga harus orang yang memiliki kredibilaitas dan dedikasi yang kualifiet. Setidaknya memenuhi beberapa syarat diantaranya dia harus mampu melaksanakan, cermat, objektif, sabar dan tekun dan hati-hati dan bertanggung jawab. Kedua adalah audit eksternal yaitu evaluasi atau audit yang dilakukan oleh instansi atau dinas terkait seperti audit atau supervisi yang dilakukan oleh dinas pendidikan atau pengawas kantor kementerian agama. Supervisi lembaga pendidikan bisa juga dilakukan oleh lembaga swasta yang memiliki kompetensi dan relefansi pada lembaga pendidikan, misalnya relefansi yang spesifikasinya mengarah pada managemen pendidikan, misalnya quality standart management ISO (international standardization of organization) 9001 oleh SAI GLOBAL. Yang mana lembaga pendidikan bekerja sama dengan SAI GLOBAL dalam upaya menciptakan manajemen lembaga pendidikan, mulai dari konsep, aplikasi sampai pada tataran supervisi atau audit administrasi dan pelayanan public. Sikap inovatif dan keterbukaan, mau menerima evaluasi serta kontribusi konsep yang konstruktif adalah resep awal kemajuan lembaga pendidikan, khususnya lembaga pendidikan islam. Atas dasar inilah kiranya proses supervisi dan peran supervisor yang benar-benar memiliki kompetensi dan professional sangat diharapkan dan sebuah keharusan.

Ada berbagai macam konsep sepervisi, yang dalam nomenklatur system pendidikan nasional oleh kementerian pendidikan kebudayaan disebut dengan pengawasan. Secara historis supervisi dimaknai sebagai inspeksi, pengawasan yang bertujuan untuk mencari-cari kesalahan dan selanjutnya dilakukan perbaikan. Pada pengawasan tadisional supervisi menempati posisi sebagai snooper vision. Yaitu memata-matai untuk mencari kesalahan. Dilatar belakangi persoalan inilah supervisi atau pengawasan justru menjadi sesuatu yang sangat menakutkan dimata para guru, dan akibatnya supervisi dalam pendidikan tidak berperan sebagaimana konsep idealnya.

Kepala sekolah dituntut memiliki kompetensi dalam membina guru-guru. Dalam Peraturan Menteri Pendidikan Nasional No. 13
Tahun 2007 tentang Standar Kepala Sekolah/Madrasah, ditegaskan bahwa seorang kepala sekolah/madrasah harus memiliki kompetensi kepribadian, manajerial, kewirausahaan, supervisi, dan sosial. Semua kompetensi tersebut mutlak harus dimiliki oleh kepala sekolah agar mampu mewujudkan pembelajaran yang bermutu dalam rangka mencapai pendidikan yang berkualitas di sekolah. Kepala sekolah lebih dekat dengan sekolah bahkan melekat pada kehidupan sekolah yang lebih banyak mengarahkan perhatiannya pada supervisi pengajaran/ akademik. (Suharsimi Arikunto, 2004:7)

Untuk melaksanakan supervisi akademik secara efektif diperlukan keterampilan konseptual, interpersonal dan teknikal (Glickman, C.D., Gordon, S.P., and Ross-Gordon, 2007). Oleh sebab itu, setiap Kepala Satuan Pendidikan harus memiliki dan menguasai konsep supervisi akademik yang meliputi: pengertian, tujuan dan fungsi, prinsip-prinsip, dan dimensi-dimensi substansi supervisi akademik. Supervisi akademik yang dilakukan kepala Satuan Pendidikan antara lain adalah sebagai berikut.:

1. Memahami konsep, prinsip, teori dasar, karakteristik, dan kecenderungan perkembangan tiap bidang pengembangan mata kuliah di Satuan Pendidikan.

2. Memahami konsep, prinsip, teori / teknologi, karakteristik, dan kecenderungan perkembangan proses pembelajaran/ bimbingan tiap bidang pengembangan mata kuliah di Satuan Pendidikan.

3. Membimbing dosen atau instruktur dalam menyusun silabus tiap bidang pengembangan mata kuliah di Satuan Pendidikan berlandaskan standar isi, standar kompetensi dan kompetensi dasar, dan prinsip-prinsip pengembangan KTSP.

4. Membimbing dosen atau instruktur dalam memilih dan menggunakan strategi/ metode/teknik pembelajaran/bimbingan yang dapat mengembangkan berbagai potensi siswa melalui bidang pengembangan mata kuliah di Satuan Pendidikan.

5. Membimbing dosen atau instruktur dalam menyusun Rencana Pelaksanaan Pembelajaran 
(RPP) untuk tiap bidang pengembangan mata kuliah di Satuan Pendidikan.

6. Membimbing dosen atau instruktur dalam melaksanakan kegiatan pembelajaran/ bimbingan (di kelas, laboratorium, dan/atau di lapangan) untuk mengembangkan potensi siswa pada tiap bidang pengembangan mata kuliah di Satuan Pendidikan.

7. Membimbing dosen atau instruktur dalam mengelola, merawat, mengembangkan dan menggunakan media pendidikan dan fasilitas pembelajaran/ bimbingan tiap bidang pengembangan mata kuliah di Satuan Pendidikan.

8. Memotivasi dosen atau instruktur untuk memanfaatkan teknologi informasi untuk pembelajaran/ bimbingan tiap bidang pengembangan mata kuliah Satuan Pendidikan.

Pelaksanaannya supervisi dalam lembaga pendidikan masih menemui berbagai kendala baik itu dalam teknik penyampaian maupun intensitas pelaksanaan supervisi yang dilakukan belum ditetapkan dengan baik sehingga kepala sekolah masih insidental mengadakan pembinaan dan pelatihan kepada guru dalam proses pembelajaran. Dalam kenyataannya kepala sekolah belum dapat melaksanakan supervisi dengan baik dengan alasan beban kerja kepala sekolah yang terlalu berat serta latar belakang pendidikan yang kurang sesuai dengan bidang studi yang disupervisi. (Suharsimi Arikunto, 2004:4) Sehingga tujuan untuk membina dan membimbing guru masih belum sempurna serta guru kurang memahami makna dari pentingnya supervisi yang dilakukan oleh kepala sekolah. Oleh sebab itu, penulis akan menulis mengenai supervisi akademik kepala sekolah dalam meningkatkan proses pembelajaran di sekolah.

\section{PEMBAHASAN}

\section{Konsep Supervisi Akademik}

Supervisi akademik adalah serangkaian kegiatan membantu guru mengembangkan kemampuannya dalam mengelola proses pembelajaran untuk mencapai tujuan pembelajaran (Glickman, C.D., Gordon, S.P., and Ross-Gordon, 2007). (Sullivan, S. \& Glanz, 2005) menyebutkan
Supervisi akademik tidak terlepas dari penilaian kinerja dosen atau instruktur dalam mengelola pembelajaran. (Sergiovanni, n.d.) menegaskan bahwa refleksi praktis penilaian kinerja dosen atau instruktur dalam supervisi akademik adalah melihat kondisi nyata kinerja guru untuk menjawab pertanyaan-pertanyaan, misalnya apa yang sebenarnya terjadi di dalam kelas?, apa yang sebenarnya dilakukan oleh dosen atau instruktur dan siswa di dalam kelas?, aktivitas-aktivitas mana dari keseluruhan aktivitas di dalam kelas itu yang bermakna bagi dosen atau instruktur dan mahasiswa?, apa yang telah dilakukan oleh dosen atau instruktur dalam mencapai tujuan akademik?, apa kelebihan dan kekurangan dosen atau instruktur dan bagaimana cara mengembangkannya?.

Berdasarkan jawaban terhadap pertanyaan pertanyaan ini akan diperoleh informasi mengenai kemampuan dosen atau instruktur dalam mengelola pembelajaran. Namun satu hal yang perlu ditegaskan di sini, bahwa setelah melakukan penilaian kinerja berarti selesailah pelaksanaan supervisi akademik, melainkan harus dilanjutkan dengan tindak lanjutnya berupa pembuatan program supervisi akademik dan melaksanakannya dengan sebaikbaiknya.

\section{Tujuan dan Fungsi Supervisi Akademik}

Tujuan supervisi akademik menurut (Glickman, C.D., Gordon, S.P., and Ross-Gordon, 2007), (Sergiovanni, n.d.) dan (Robbins, 2008) adalah:

a. membantu dosen atau instruktur mengembangkan kompetensinya,

b. mengembangkan kurikulum,

c. mengembangkan kelompok kerja dosen atau instruktur, dan membimbing penelitian tindakan kelas (PTK).

Gambar tiga tujuan supervisi akademik sebagaimana dapat dilihat pada gambar di bawah ini. 


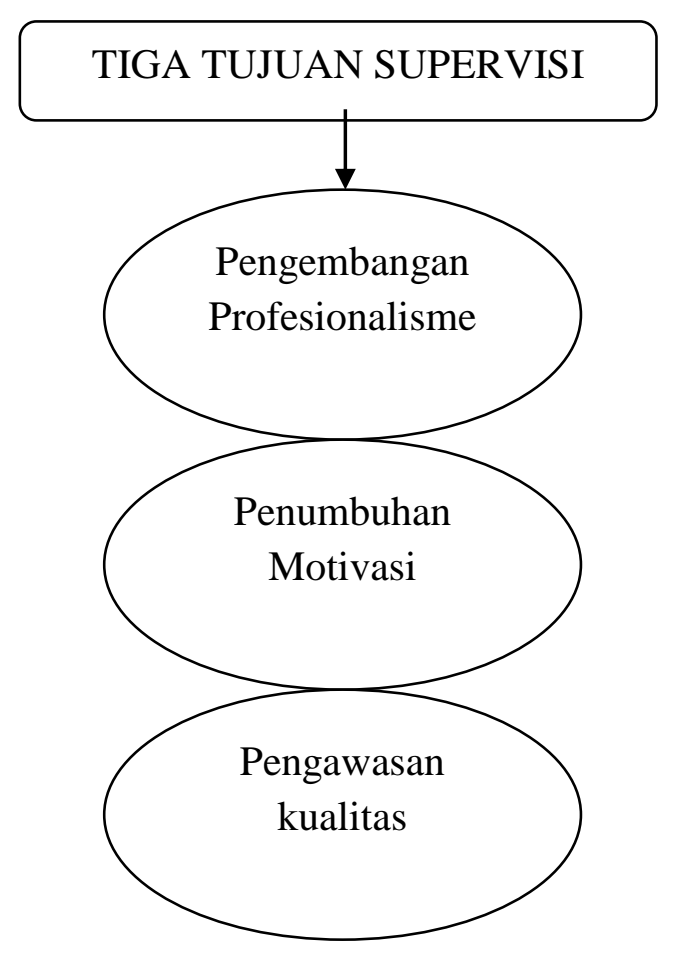

Supervisi akademik merupakan salah satu (fungsi mendasar (essential function) dalam keseluruhan program Satuan Pendidikan (Weingartner, 1973; Alfonso dkk., 1981; dan (Glickman, C.D., Gordon, S.P., and Ross-Gordon, 2007)). Hasil supervisi akademik berfungsi sebagai sumber informasi bagi pengembangan profesionalisme dosen atau instruktur.

\section{Prinsip-Prinsip Supervisi Akademik}

a. Praktis, artinya mudah dikerjakan sesuai kondisi Satuan Pendidikan.

b. Sistematis, artinya dikembangan sesuai perencanaan program supervisi yang matang dan tujuan pembelajaran.

c. Objektif, artinya masukan sesuai aspek-aspek instrumen.

d. Realistis, artinya berdasarkan kenyataan sebenarnya.

e. Antisipatif, artinya mampu menghadapi masalah-masalah yang mungkin akan terjadi. f. Konstruktif, artinya mengembangkan kreativitas dan inovasi dosen atau instruktur dalam mengembangkan proses pembelajaran.

g. Kooperatif, artinya ada kerja sama yang baik antara supervisor dan dosen atau instruktur dalam mengembangkan pembelajaran.

h. Kekeluargaan, artinya mempertimbangkan saling asah, asih, dan asuh dalam mengembangkan pembelajaran.

i. Demokratis, artinya supervisor tidak boleh mendominasi pelaksanaan supervisi akademik.

j. Aktif, artinya dosen atau instruktur dan supervisor harus aktif berpartisipasi.

k. Humanis, artinya mampu menciptakan hubungan kemanusiaan yang harmonis, terbuka, jujur, ajeg, sabar, antusias, dan penuh humor. (Dodd. W. A., 1972)

1. Berkesinambungan (supervisi akademik dilakukan secara teratur dan berkelanjutan oleh Kepala satuan pendidikan).

m. Terpadu, artinya menyatu dengan dengan program pendidikan.

n. Komprehensif, artinya memenuhi ketiga tujuan supervisi akademik di atas.

\section{Dimensi-Dimensi Subtansi Supervisi Akademik}

a. Kompetensi kepribadian.

b. Kompetensi pedagogik.

c. Kompotensi profesional.

d. Kompetensi social

\section{Teknik-Teknik Supervisi Akademik}

Teknik supervisi akademik ada dua, yaitu teknik supervisi individual dan teknik supervisi kelompok.

\section{a. Teknik supervisi individual}

Teknik supervisi individual adalah pelaksanaan supervisi perseorangan terhadap dosen atau instruktur. Supervisor di sini hanya berhadapan 
dengan seorang dosen atau instruktur sehingga dari hasil supervisi ini akan diketahui kualitas pembelajarannya.

\section{b. Macam-macam teknik supervise individual}

Teknik supervisi individual ada lima macam menurut (Verma, 1996) yaitu:

\section{1) Kunjungan kelas,}

Kunjungan kelas adalah teknik pembinaan dosen atau instruktur oleh kepala Satuan Pendidikan untuk mengamati proses pembelajaran di kelas. Tujuannya adalah untuk menolong dosen atau instruktur dalam mengatasi masalah di dalam kelas.

\section{a). Melaksanakan kunjungan kelas}

Cara melaksanakan kunjungan kelas:

1) Dengan atau tanpa pemberitahuan terlebih dahulu tergantung sifat tujuan dan masalahnya,

2) Atas permintaan dosen atau instruktur bersangkutan,

3) Sudah memiliki instrumen atau catatan-catatan,

4) Tujuan kunjungan harus jelas.

\section{b). Tahap-tahap kunjungan kelas}

Ada empat tahap kunjungan kelas.

1) Tahap persiapan. Pada tahap ini, supervisor merencanakan waktu, sasaran, dan cara mengobservasi selama kunjungan kelas.

2) Tahap pengamatan selama kunjungan. Pada tahap ini, supervisor mengamati jalannya proses pembelajaran berlangsung.

3) Tahap akhir kunjungan. Pada tahap ini, supervisor bersama dosen atau instruktur mengadakan perjanjian untuk membicarakan hasilhasil observasi.

4) Tahap terakhir adalah tahap tindak lanjut.

\section{2) Observasi Kelas,}

Observasi kelas adalah mengamati proses pembelajaran secara teliti di kelas. Tujuannya adalah untuk memperoleh data obyektif aspekaspek situasi pembelajaran, kesulitan-kesulitan dosen atau instruktur dalam usaha memperbaiki proses pembelajaran.

\section{a) Aspek-aspek yang diobservasi di dalam kelas}

Secara umum, aspek-aspek yang diobservasi adalah:

1) usaha-usaha dan aktivitas dosen atau instruktur- siswa dalam proses pembelajaran,

2) cara menggunakan media pengajaran

3) variasi metode,

4) ketepatan penggunaan media dengan materi

5) ketepatan penggunaan metode dengan materi, dan

6) reaksi mental para siswa dalam proses belajar mengajar.

\section{b) Pelaksanaan observasi kelas}

Pelaksanaan observasi kelas ini melalui tahap:

1) persiapan,

2) pelaksanaan,

3) penutupan,

4) penilaian hasil observasi,

5) tindak lanjut.

\section{3) Pertemuan Individual,}

Pertemuan individual adalah satu pertemuan, percakapan, dialog, dan tukar pikiran antara supervisor dosen atau instruktur. Tujuannya adalah:

1) memberikan kemungkinan pertumbuhan jabatan dosen atau instruktur melalui pemecahan kesulitan yang dihadapi;

2) mengembangkan hal mengajar yang lebih baik; 
3) memperbaiki segala kelemahan dan kekurangan pada diri dosen atau instruktur;

4) menghilangkan atau menghindari segala prasangka.

\section{a). Jenis-jenis pertemuan individual}

Swearingen (1961) mengklasifikasi empat jenis pertemuan (percakapan) individual sebagai berikut

1) classroom-conference, yaitu percakapan individual yang dilaksanakan di dalam kelas ketika mahasiswa-mahasiswa sedang meninggalkan kelas (istirahat).

2) office-conference, yaitu percakapan individual yang dilaksanakan di ruang kepala Satuan Pendidikan atau ruang dosen atau instruktur, di mana sudah dilengkapi dengan alat-alat bantu yang dapat digunakan untuk memberikan penjelasan pada dosen atau instruktur.

3) causal-conference, yaitu percakapan individual yang bersifat informal, yang dilaksanakan secara kebetulan bertemu dengan dosen atau instruktur

4) observational visitation, yaitu percakapan individual yang dilaksanakan setelah supervisor melakukan kunjungan kelas atau observasi kelas.

\section{4) Kunjungan Antarkelas}

Kunjungan antar kelas adalah dosen atau instruktur yang satu berkunjung ke kelas yang lain di Satuan Pendidikan itu sendiri. Tujuannya adalah untuk berbagi pengalaman dalam pembelajaran.

\section{a). Cara-cara melaksanakan kunjungan antar kelas}

Cara-cara melakukan kunjungan antar kelas:

1) harus direncanakan;

2) dosen atau instruktur yang akan dikunjungi harus diseleksi;

3) tentukan dosen atau instruktur-dosen atau instruktur yang akan mengunjungi;
4) sediakan segala fasilitas yang diperlukan;

5) supervisor hendaknya mengikuti acara ini dengan pengamatan yang cermat;

6) adakah tindak lanjut setelah kunjungan antar kelas selesai, misalnya dalam bentuk percakapan pribadi, penegasan, dan pemberian tugas-tugas tertentu;

7) segera aplikasikan ke Satuan Pendidikan atau ke kelas dosen atau instruktur bersangkutan, dengan menyesuaikan pada situasi dan kondisi yang dihadapi;

8) adakan perjanjian-perjanjian untuk mengadakan kunjungan antar kelas berikutnya.

\section{5) Menilai Diri Sendiri.}

Menilai diri adalah penilaian diri yang dilakukan oleh diri sendiri secara objektif. Untuk maksud itu diperlukan kejujuran diri sendiri.

\section{a). Cara-cara menilai diri sendiri}

Cara-cara menilai diri sendiri sebagai berikut.

1) Suatu daftar pandangan atau pendapat yang disampaikan kepada mahasiswa-mahasiswa untuk menilai pekerjaan atau suatu aktivitas. Biasanya disusun dalam bentuk pertanyaan baik secara tertutup maupun terbuka, dengan tidak perlu menyebut nama.

2) Menganalisa tes-tes terhadap unit kerja.

3) Mencatat aktivitas mahasiswa-mahasiswa dalam suatu catatan, baik mereka bekerja secara individu maupun secara kelompok.

\section{Supervisi Kelompok}

Teknik supervisi kelompok adalah satu cara melaksanakan program supervisi yang ditujukan pada dua orang atau lebih. Dosen atau instrukturdosen atau instruktur yang diduga, sesuai dengan analisis kebutuhan, memiliki masalah atau kebutuhan atau kelemahankelemahan yang sama dikelompokkan atau dikumpulkan menjadi satu/bersama-sama. Kemudian kepada mereka diberikan layanan supervisi sesuai dengan permasalahan atau kebutuhan yang mereka hadapi. 
Menurut (Gwynn, 1961), ada tiga belas teknik supervisi kelompok yaitu:

1) kepanitiaan-kepanitiaan,

2) kerja kelompok,

3) laboratorium dan kurikulum,

4) membaca terpimpin,

5) demonstrasi pembelajaran,

6) darmawisata,

7) kuliah/studi,

8) diskusi panel,

9) perpustakaan,

10) organisasi profesional,

11) buletin supervisi,

12) pertemuan dosen atau instruktur,

13) lokakarya atau konferensi kelompok

Tidak satupun di antara teknik-teknik supervisi individual atau kelompok di atas yang cocok atau bisa diterapkan untuk semua pembinaan dosen atau instruktur di Satuan Pendidikan. Oleh sebab itu, seorang kepala Satuan Pendidikan harus mampu menetapkan teknikteknik mana yang sekiranya mampu membina keterampilan pembelajaran seorang dosen atau instruktur. Untuk menetapkan teknikteknik supervisi akademik yang tepat tidaklah mudah. Seorang kepala Satuan Pendidikan, selain harus mengetahui aspek atau bidang keterampilan yang akan dibina, juga harus mengetahui karakteristik setiap teknik di atas dan sifat atau kepribadian dosen atau instruktur sehingga teknik yang digunakan betul-betul sesuai dengan dosen atau instruktur yang sedang dibina melalui supervisi akademik. Sehubungan dengan kepribadian dosen atau instruktur, Lucio dan McNeil (1979) menyarankan agar kepala Satuan Pendidikan mempertimbangkan enam faktor kepribadian dosen atau instruktur, yaitu kebutuhan dosen atau instruktur, minat dosen atau instruktur, bakat dosen atau instruktur, temperamen dosen atau instruktur, sikap dosen atau instruktur, dan sifatsifat somatic dosen atau instruktur.

\section{SIMPULAN DAN SARAN}

Supervisi akademik adalah serangkaian kegiatan membantu guru mengembangkan kemampuannya dalam mengelola proses pembelajaran untuk mencapai tujuan pembelajaran. Teknik-teknik supervisi akademik ada dua, yaitu teknik individual dan teknik kelompok. supervisi klinis bagi dosen atau instruktur muncul ketika dosen atau instruktur tidak harus disupervisi atas keinginan kepala Satuan Pendidikan sebagai supervisor tetapi atas kesadaran dosen atau instruktur untuk datang ke supervisor untuk minta bantuan mengatasi masalahnya.

\section{DAFTAR RUJUKAN}

Dodd. W. A. (1972). Primary School Inspection in New Countries. London: Oxford University Press.

Glickman, C.D., Gordon, S.P., and Ross-Gordon, J. M. (2007). Supervision and Instructional Leadership A Development Approach. Boston: Perason.

Gwynn, J. . (1961). Theory and Practice of Supervision. New York: Dodd, Mead \& Company.

Robbins, S. . (2008). The Truth about Managing People. Second Edition. New Jersey: Pearson Education, Inc.

Sergiovanni, T. . (n.d.). Supervision of Teaching. Alexandria: Association for Supervision and Curriculum Development.

Suharsimi Arikunto. (2004). Dasar-Dasar Supervisi. jakarta: PT. Rineka Cipta.

Sullivan, S. \& Glanz, J. (2005). Supervision that Improving Teaching Strategies and Techniques. Thousand Oaks. California: Corwin Press.

Verma, V. . (1996). The Human Aspects of Project Management Human Resources Skills for the Project Manager (Volume Two). Project 
Management Institute. 